\title{
Pengaruh Modal Teknologi Informasi Dan Komunikasi Terhadap Kinerja Inovasi
}

\author{
Pungki Andriani Setiadi1 \\ Fakultas Ekonomi dan Bisnis \\ Universitas Airlangga, Indonesia \\ Email: pungki.setiadi94@gmail.com
}

\author{
I Made Narsa ${ }^{2}$ \\ Fakultas Ekonomi dan Bisnis \\ Universitas Airlangga, Indonesia
}

\begin{abstract}
ABSTRAK
Penelitian ini bertujuan untuk menginvestigasi hubungan antara modal teknologi informasi dan komunikasi (ICT) terhadap kinerja inovasi. Teknologi informasi dan komunikasi terdiri dari ICT infrasatruktur, ICT personel, ICT training, dan ICT departemen. Metode penelitian ini menggunakan metode kuantitatif deskriptif dengan kuesioner sebagai metode perolehan data. Subjek penelitian ini berjumlah 70 responden yang diambil dengan random sampling method dari berbagai perusahaan manufaktur di Surabaya. Teknik analisis data menggunakan Partial Least-Square (PLS). Hasil penelitian ini menunjukkan bahwa ICT infrastruktur dan ICT training berpengaruh signifikan terhadap kinerja inovasi. Sedangkan, ICT personel dan ICT departemen tidak berpengaruh signifikan terhadap kinerja inovasi.
\end{abstract}

Kata Kunci : $\quad$ ICT Infrastruktur; ICT Personel; ICT Training; ICT Departemen; Kinerja Inovasi.

\section{The Effect Of Information And Communication Technologies Capital On Innovation Performance}

\begin{abstract}
This study aims to investigate the relationship between Information and Communication Technologies (ICT) on innovation performance. Information and Communication Technologies consist of ICT Infrastructure, ICT Personnel, ICT Training, and ICT Department. This research method uses descriptive quantitative method with a questionnaire as a method of data acquisition. The subjects of this study were 70 respondents taken by random sampling method from various manufacturing companies in Surabaya. Data analysis techniques using Partial Least-Square (PLS). The results of this study indicate that ICT Infrastructure and ICT Training have a significant effect on innovation performance. Meanwhile, ICT Personnel and ICT Department did not significantly influence innovation performance.
\end{abstract}

Keywords: $\quad$ ICT Infrastructure; ICT Personnel; ICT Training; ICT Department; Innovation Performance.

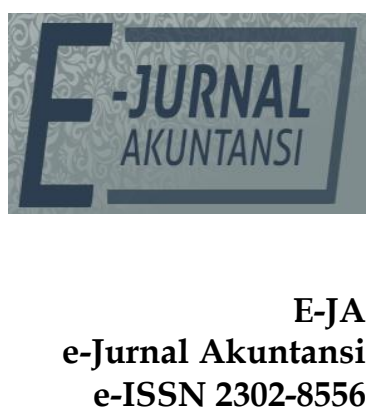

Vol. 29 No. 2

Denpasar, November 2019

Hal. 727-741

Artikel masuk: 13 September 2019

Tanggal diterima: 18 November 2019 


\section{PENDAHULUAN}

Teknologi informasi dan komunikasi (ICT) memiliki potensi besar untuk meningkatkan efisiensi bisnis didalam perusahaan, dimana mereka memproduksi produk dan layanan mereka (Arvanitis, Loukis, \& Diamantopoulou, 2013). ICT juga memfasilitasi dan mendorong inovasi, baik didalam proses, produk maupun layanannya. Inovasi merupakan elemen penting ekonomi modern, yang sangat penting bagi kemakmuran perusahaan, industri, dan negara. Inovasi dalam produk atau layanan dapat membuat perusahaan menciptakan pasar baru, berbeda dari pesaingnya, atau melakukan ekspansi ke industri lain. Inovasi dalam proses menciptakan metode baru di perusahaan dalam melakukan aktivitasnya. Hal ini dapat membuat perusahaan memiliki biaya yang rendah, efisiensi yang lebih tinggi, atau menghasilkan pendapatan baru dan memiliki dampak positif terhadap profitabilitasnya. Kemampuan perusahaan dalam melakukan inovasi pada prosesnya, atau memperbaharui prosesnya, sangat penting untuk kelangsungan hidup perusahaan (Arvanitis et al., 2013).

Banyak proses saat ini, produk, dan layanan perusahaan yang dirancang dan ditetapkan di era pra-ICT, sehingga proses, produk, dan layanan perusahaan telah dibentuk untuk sebagian karakteristik dasar, keterbatasan kerja manual, dan tingginya biaya dalam proses informasi dan transfer saat itu. ICT mengatasi keterbatasan itu dan mengurangi proses informasi dan biaya transfer (Davenport, 1993), menawarkan kemampuan dan peluang untuk inovasi dalam proses, produk, dan layanan perusahaan. ICT juga mempunyai potensi untuk mendukung dan meningkatkan pengumpulan dan manajemen pengetahuan yang berkaitan dengan inovasi, inovasi produk dan kolaborasi inovasi eksternal, dan meningkatkan produktivitas proses penciptaan inovasi perusahaan (Thomke, 2006).

Ada beberapa literatur yang membahas mengenai potensi inovasi ICT (Bresnahan et al., 2002; Davenport, 1993; Thomke, 2006; Wu \& Hisa, 2008). Namun, penelitian mereka terbatas pada modal keras ICT (hard ICT), seperti perangkat atau peralatan ICT, dan mengabaikan modal lunak ICT (soft ICT), seperti keahlian dan pengetahuan ICT. Tujuan penelitian ini adalah untuk mengivestigasi hubungan antara Information and Communication Technologies (ICT) dan innovation performance. Didalam artikel ini, ICT difokuskan terhadap soft ICT. Soft ICT terdiri dari empat dimensi yaitu ICT infrastructure, ICT personnel, ICT training, dan ICT department.

Technology Acceptance Model (TAM) merupakan suatu model penerimaan sistem teknologi informasi yang akan digunakan oleh pengguna (user). TAM, diperkenalkan oleh Davis (1989) merupakan adaptasi dari Theory of Reasoned Action (TRA) yang dikhususkan untuk model penerimaan sistem informasi. Tujuan TAM adalah memberikan penjelasan mengenai faktor-faktor penentu penerimaan komputer yang bersifat umum, mampu menjelaskan perilaku pengguna di berbagai bidang teknologi dan pengguna komputer. Ada lima konstruk dalam TAM yaitu perceived usefulness, perceived ease of use, attitude toward using, behavioral intention to use, dan actual system use. Perceived usefulness didefinisikan sebagai sejauh mana seseorang percaya bahwa menggunakan suatu teknologi akan meningkatkan kinerjanya (Ardhiani, 2015; Davis, 1986, 
1989; Davis et al., 1989). Jika seseorang percaya bahwa sistem informasi berguna, maka dia akan menggunakan sistem informasi tersebut. Davis (1989) dan Davis et al. (1989) menunjukkan bahwa perceived usefulness merupakan konstruk yang paling penting dan signifikan dalam mempengaruhi sikap, niat, dan perilaku seseorang dalam menggunakan teknologi.

Perceived ease of use didefinisikan sebagai sejauh mana seseorang percaya bahwa menggunakan suatu teknologi akan bebas dari usaha (Ardhiani, 2015; Davis, 1989; Davis et al., 1989). Artinya, jika seseorang percaya bahwa sistem informasi mudah digunakan, maka dia akan menggunakan sistem informasi tersebut. Davis (1989) menunjukkan bahwa konstruk ini mempengaruhi perceived usefulness, sikap, niat, dan perilaku. Attitude toward using didefinisikan sebagai perasaan-perasaan positif atau negatif dari seseorang jika harus melakukan perilaku yang ditentukan (Ardhiani, 2015; Davis et al., 1989). Ardhiani (2015) menunjukkan bahwa sikap berpengaruh positif terhadap niat perilaku (behavioral intention). Behavioral intention atau niat perilaku merupakan suatu niat seseorang untuk melakukan suatu perilaku jika mempunyai niat untuk melakukannya (Ardhiani, 2015; Davis et al., 1989). Ardhiani (2015) menunjukkan bahwa niat perilaku merupakan prediksi yang baik dari penggunaan teknologi. Actual system use adalah suatu tindakan yang dilakukan oleh seseorang dalam menggunakan teknologi (Ardhiani, 2015; Davis et al., 1989).

Berdasarkan theory acceptance model (TAM), penggunaan information and communication technologies (ICT) ditentukan oleh persepsi seseorang mengenai kegunaan (perceived usefulness) dan kemudahan penggunaan (perceived ease of use). Jika seseorang mempunyai persepsi atau percaya bahwa ICT berguna bagi pekerjaan mereka dan mudah digunakan, maka seseorang tersebut menggunakan ICT dengan baik. Penggunaan ICT berpotensi untuk meningkatkan efisiensi proses bisnis didalam perusahaan, dimana produk dan layanan yang biasa mereka produksi. Selain itu, ICT memfasilitasi dan mendorong inovasi penting dalam proses, produk, dan layanan. ICT dicirikan dengan tingkat fleksibilitas yang tinggi dan kemampuan beradaptasi, sehingga dapat digunakan dengan berbagai cara oleh perusahaan dan untuk berbagai tujuan yang memungkinkan inovasi penting dalam proses bisnis, produk, dan layanan (Bresnahan \& Trajtenberg, 1995). ICT telah mengurangi pemrosesan informasi secara dramatis dan mentransfer biaya, dan memungkinkan mengatasi keterbatasan sebelumnya dari pekerjaan manual. Oleh karena itu, ICT mengarah pada peningkatan baru proses bisnis dan praktik kerja, yang menghasilkan peningkatan produktivitas yang besar dengan mengurangi biaya dan meningkatkan kualitas hasil. Setelah itu, mereka dapat mendorong desain produk/layanan yang baru, dan peningkatan signifikan dari aspek-aspek, seperti kenyamanan, kualitas, dan lain-lain. ICT dapat mengubah cara kerja manusia, terkontrol dan terkoordinasi, dan memungkinkan restrukturisasi praktik kerja yang signifikan (Arvanitis et al., 2013). ICT secara signifikan dapat membantu meningkatkan pengumpulan, manajemen, dan pertukaran pengetahuan terkait inovasi (Gordon et al., 2008; Kleis et al., 2012). ICT memungkinkan komunikasi dan pertukaran pengetahuan yang lebih baik diantara karyawan perusahaan diberbagai fungsi, serta memfasilitasi kombinasi pengetahuan ilmiah yang sangat penting untuk inovasi (Arvanitis et al., 2013). Produk inovasi dapat 
ditingkatkan melalui metode perancangan berbasis ICT, membuat prototype baru, dan menguji produk baru. Pada saat yang sama, jaringan elektronik mendukung dan meningkatkan kolaborasi inovasi eksternal, dimana perusahaan memperoleh akses ke pengetahuan khusus yang dapat digunakan untuk merancang produk, layanan, dan proses baru. Penerapan ICT menjadi infrastruktur inovasi yang penting untuk langkah bertahap dari paradigm inovasi tertutup, dimana perusahaan menghasilkan ide untuk produk dan layanan yang inovatif, dan kemudian mengembangkan, memproduksi, memasarkan dan mendistribusikannya sendiri, untuk lebih produktif dari paradigm inovasi terbuka (Chesbrough \& Crowther, 2006; Chesbrough, 2003), dimana ide internal dan eksternal, keterampilan, dan pengetahuan digabungkan untuk menciptakan inovasi yang lebih baik dalam waktu yang lebih singkat dan mempromosikannya di berbagai pasar.

Penelitian sistem informasi sebelumnya mengungkapkan bahwa perusahaan-perusahaan yang mengeksploitasi ICT sangat penting untuk mengembangkan hard ICT dan soft ICT. (Mata et al., 1995) menyelidiki potensi ICT untuk menciptakan berkelanjutan keunggulan kompetitif dengan memeriksa empat "atribut" dasar ICT pada tingkat perusahaan: teknologi eksklusif, teknik keterampilan ICT, keterampilan TIK manajerial dan akses ke modal. Mereka menyimpulkan bahwa hanya keterampilan TIK manajerial yang sangat mungkin untuk memberikan keunggulan kompetitif yang berkelanjutan; sebaliknya kemampuannya teknologi (bahkan yang eksklusif) untuk memberikan keunggulan kompetitif yang berkelanjutan dinilai sebagai rendah (Barney, 1991). Brynjolfsson \& Hitt (1996) meneliti tidak hanya dampak ICT capital dan non-ICT capital pada kinerja keuangan, tetapi juga dampak dari tenaga kerja ICT dan tenaga kerja non-ICT. Mereka menemukan bahwa tenaga kerja ICT berpengaruh signifikan dan positif terhadap output perusahaan, dan produk marjinal lebih tinggi dari salah satu tenaga kerja non-ICT.

Bharadwaj (2000) menyelidiki dampak dari hard ICT capital dan beberapa jenis soft ICT capital pada berbagai laba dan berbasis biaya ukuran kinerja. Dia menemukan ICT resources, yang terdiri dari ICT physical infrastructure, human ICT resources, dan ICT-enabled intangibles, menghasilkan kinerja yang baik. Wade \& Hulland (2004) mengidentifikasi delapan jenis sumber daya ICT dan kemampuan yang dibutuhkan perusahaan untuk mengeksploitasi potensi ICT, dari hard ICT capital (infrastruktur sistem informasi), dan soft ICT capital (keterampilan teknis, pengembangan, dan operasi sistem informasi, kemitraan dan perencanaan bisnis sistem informasi, dan respon pasar dan eksternal manajemen hubungan). Ravichandran \& Lertwongsatien (2005) memperkirakan model yang menghubungkan kecanggihan ICT infrastruktur (platform dasar perusahaan, jaringan, aplikasi dan data), IS human capital (sama dengan keterampilan personil sistem informasi dan pengetahuan tentang teknologi dan operasi perusahaan) dan kualitas kemitraan sistem informasi (baik internal maupun eksternal) pada lapisan pertama, dengan beberapa kemampuan sistem informasi yang penting (untuk perencanaan sistem informasi, pengembangan dan pengoperasian) pada lapisan kedua, hasil dukungan ICT yang disediakan untuk fungsi bisnis utama pada lapisan ketiga dan akhirnya keuangan kinerja. Mereka menemukan bahwa semua sumber daya sistem informasi lapisan 
pertama memiliki dampak positif pada kemampuan sistem informasi pada lapisan kedua, dengan dampak dari IS human capital menjadi yang terkuat.

ICT infrastruktur sangat penting bagi perusahaan. ICT infrastruktur membantu karyawan dalam melaksanakan kegiatan operasional perusahaan. Perusahaan menginvestasikan ICT infrastruktur (platform dasar, jaringan, aplikasi, dan data) untuk meningkatkan kinerja inovasi didalam perusahaan. Kecanggihan ICT infrastruktur akan membuat karyawan lebih mudah mengakses pengetahuan terkait dengan inovasi, yang akan menghasilkan inovasi baru dalam hal proses, produk, dan layanan. Berdasarkan uraian tersebut, hipotesis penelitiannya adalah :

$\mathrm{H}_{1}$ : ICT infrastruktur berpengaruh terhadap kinerja inovasi.

ICT personel memiliki pengetahuan yang sangat berharga tentang kemampuan hard ICT capital perusahaan (peralatan, perangkat lunak, jaringan), dan ICT pada umumnya. Kombinasi pengetahuan antara pengetahuan produksi dan personil operasi dapat menyebabkan ide untuk inovasi proses berbasis ICT yang mengeksploitasi kemampuan yang ditawarkan oleh ICT. Kombinasi antara pengetahuan ICT dengan pengetahuan tentang tenaga penjualan dan pemasaran (misalnya tentang pelanggan keluhan dan preferensi, penawaran pesaing, tren pasar) dapat mengarah pada gagasan untuk produk dan layanan baru berbasis ICT. Kombinasi dari pengetahuan ICT dengan pengetahuan personel R\&D dapat mengarah pada gagasan untuk menggunakan ICT guna meningkatkan produktivitas proses R\&D dan pembuatan inovasi perusahaan (misalnya untuk mendukung dan meningkatkan koleksi dan manajemen pengetahuan yang terkait dengan inovasi, yang kolaborasi inovasi eksternal dan produksi inovasi). Oleh karena itu, pengetahuan dan keterampilan personil ICT sangat penting untuk inovasi. Berdasarkan uraian tersebut, hipotesis penelitiannya adalah :

$\mathrm{H}_{2}$ : ICT personel berpengaruh terhadap kinerja inovasi.

ICT berevolusi dengan cepat sehingga menghasilkan munculnya teknologi baru secara berkelanjutan dan peningkatan kemampuan dan fleksibilitas dari yang sudah (Pawlowski \& Robey, 2004; Shih et al., 2011), yang menciptakan peluang besar untuk inovasi dalam proses, produk, dan layanan perusahaan. Oleh karena itu, karyawan dituntut untuk terus memperkaya pengetahuan dan keterampilan ICT, baik karyawan ICT maupun karyawan nonICT (pengguna ICT) melalui penyediaan pelatihan. Pelatihan tersebut akan mentransfer pengetahuan baru kepada mereka tentang kapabilitas ICT yang baru atau yang sudah ada, yang merangsang mereka untuk memikirkan ide-ide baru tentang eksploitasi ICT dalam proses dan inovasi produk/layanan, dan untuk meningkatkan produktivitas proses $R \& D$ dan pembuatan inovasi perusahaan. Penyediaan pelatihan yang cukup untuk karyawan ICT tidak hanya mempromosikan menghasilkan ide inovatif, tetapi juga penerapannya, yang memungkinkan karyawan ICT untuk menciptakan aplikasi inovatif percontohan yang lebih efisien didalam perusahaan, yang memungkinkan demonstrasi yang lebih baik tentang kegunaan dan nilainya bagi departemen bisnis lainnya. Selain itu, pelatihan ini memungkinkan karyawan ICT untuk merencanakan, menerapkan, dan mengelola eksploitasi inovatif skala besar di perusahaan. Pada saat yang sama, penyediaan pelatihan yang cukup ke karyawan non-ICT yang tepat (calon pengguna masa depan) menghasilkan hasil yang lebih baik 
kerjasama dengan karyawan ICT untuk merancang proses, produk dan layanan inovasi berdasarkan teknologi ini, dan juga penggunaannya yang lebih efisien sebagai bagian dari implementasi inovasi selanjutnya, dan kurang resistensi terhadap inovasi ini. Secara umum, transfer pengetahuan eksternal baru melalui berbagai mekanisme secara tradisional diakui sebagai dorongan penting untuk inovasi, dalam kombinasi dengan pengetahuan internal yang relevan (Cassiman \& Veugelers, 2006). Berdasarkan uraian tersebut, hipotesisnya adalah :

$\mathrm{H}_{3}$ : ICT training berpengaruh terhadap kinerja inovasi.

Secara hirarki, departemen ICT melaporkan langsung ke CEO perusahaan mengenai kinerja inovasinya. Struktur ICT ini memungkinkan disatu sisi lebih baik organisasi akuisisi, manajemen dan eksploitasi pengetahuan ICT dan keterampilan, dan disisi lain penyaluran dan arus yang lebih baik dari mereka ke fungsi perusahaan lainnya, untuk digabungkan dengan pengetahuan mereka sendiri dan memfasilitasi inovasi. Ini memungkinkan komunikasi dua arah langsung dengan CEO dan manajer dari divisi lain perusahaan, yang mempromosikan hubungan timbal balik pemahaman diantara mereka, dan penciptaan dan implementasi ide inovasi berbasis ICT. Secara khusus, departemen ICT melaporkan langsung ke CEO perusahaan yang memungkinkan transfer informasi dan pengetahuan yang lebih intensif dari departemen ICT ke CEO dan departemen lain tentang ICT yang menciptakan peluang bagi perusahaan untuk perbaikan dan pengayaan prosesnya, untuk produk dan layanan baru atau peningkatan substansial dari yang sudah ada, dan untuk penyempurnaan $R \& D$ dan proses pembuatan inovasi. Ini bisa menghasilkan lebih banyak bunga, sumber daya dan dukungan dari CEO dan departemen lain untuk percontohan dan kemudian untuk implementasi skala penuh ide-ide inovasi berbasis ICT. Pada saat yang sama, transfer informasi dan pengetahuan yang lebih intensif ke departemen ICT dari CEO dan departemen lain dapat terjadi, mengenai operasi perusahaan, masalah, tujuan dan arah strategis, yang disediakan untuk departemen ICT dengan arahan yang kuat dan motivasi untuk pemikiran, gagasan dan proposal inovatif mengenai inovasi dalam proses, produk dan layanan berbasis ICT. Penelitian sebelumnya menjelaskan bahwa pelaporan langsung dari $\mathrm{CIO}$ kepada CEO mempromosikan pemahaman bersama di antara mereka, dan antara ICT dan departemen bisnis secara umum, tentang bagaimana ICT dapat digunakan secara strategis, dan tidak hanya untuk dukungan operasional dari proses, produk dan layanan yang ada (Armstrong \& Sambamurthy, 1999; Banker et al., 2011; Chen et al., 2010). Berdasarkan uraian tersebut, hipotesis penelitiannya adalah :

$\mathrm{H}_{4}$ : ICT departemen berpengaruh terhadap kinerja inovasi. 


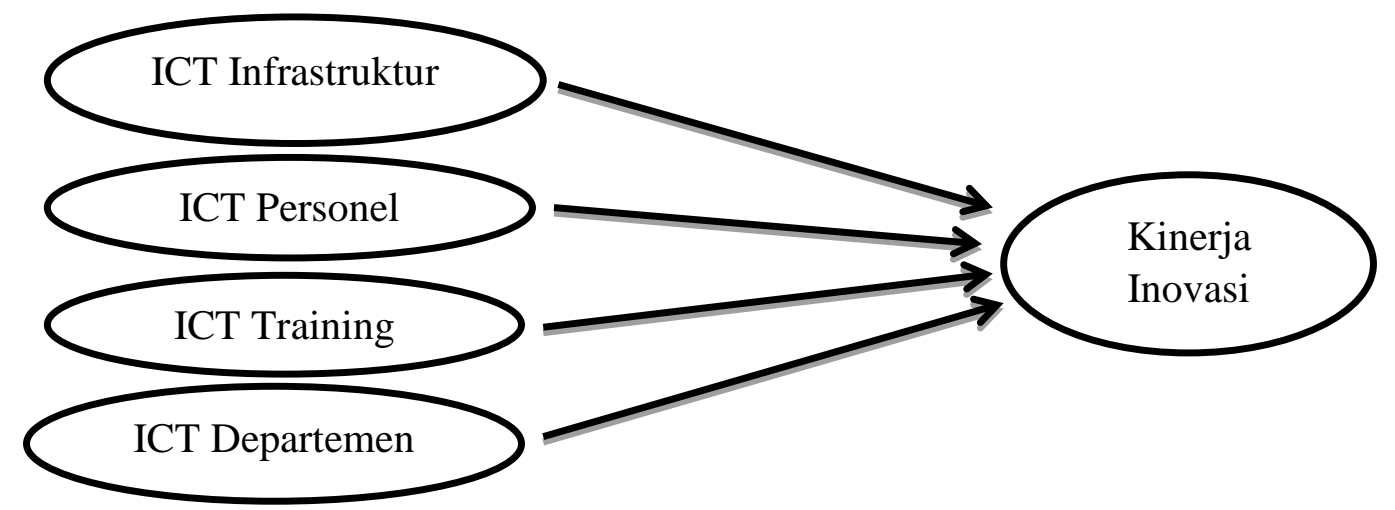

Sumber: Data Penelitian, 2018

Gambar 1. Model Penelitian

\section{METODE PENELITIAN}

Metode penelitian ini menggunakan pendekatan kuantitatif. Populasi penelitian ini adalah perusahaan manufaktur di Surabaya. Teknik pengambilan sampel dalam penelitian ini menggunakan random sampling method. Teknik pengumpulan data menggunakan kuesioner yang didistribusikan secara online. Kuesioner penelitian ini mengadopsi kuesioner dari penelitian Mafabi et al. (2015) dan Syed-Ikhsan \& Rowland (2011). Variabel dependen dalam penelitian ini adalah kinerja inovasi. Kinerja inovasi merupakan kemampuan perusahaan dalam melakukan inovasi pada prosesnya, atau memperbaharui prosesnya yang berperan penting dalam kelangsungan hidup perusahaan (Arvanitis et al., 2013). Kinerja inovasi diukur dalam 12 indikator yang dikelompokkan menjadi tiga, yaitu inovasi proses, inovasi kompetensi, dan inovasi structural. Variabel independen dalam penelitian ini adalah ICT infrastruktur, ICT personel, ICT training, dan ICT departemen. ICT infrastruktur merupakan suatu infrastruktur yang dapat membantu karyawan dalam melaksanakan kegiatan operasional perusahaan. ICT infrastruktur diukur dengan 9 indikator. ICT personel dilihat dari kualifikasi dan pengetahuan yang dimiliki oleh seorang karyawan. ICT personel diukur dengan 3 indikator. ICT training merupakan suatu pelatihan yang diselenggarakan oleh perusahaan atau instansi lainnya dalam rangka menambah pengetahuan dan keahlian para karyawan. ICT training diukur dengan 3 indikator. ICT departemen dilihat dari kemudahan akses dan pemindahan data dari setiap departemen. ICT departemen dengan 2 indikator. Masing-masing variabel dinilai dengan menggunakan skala likert 1-5 (1 = sangat tidak setuju, 5 = sangat setuju) Penelitian ini menggunakan Partial Least Square (PLS) untuk menguji hipotesisnya.

\section{HASIL DAN PEMBAHASAN}

Sebelum menguji hipotesis, data yang diperoleh harus diuji validitas dan reliabilitasnya. Hal itu dapat dilihat dari outer model dan inner model. Outer model dapat dilihat dari convergen validity. Convergent Validity dari pengukuran model dengan indikator reflektif dapat dilihat dari kolerasi antara score item/indikator dengan score strukturnya. Indikator individu dianggap reliable jika memiliki nilai korelasi diatas 0,70. Namun, pada riset tahap pengembangan skala loading 0,50 
sampai 0,60 masih dapat diterima. Suatu indikator dinyatakan valid jika mempunyai loading factor di atas 0,70 terhadap konstruk yang dituju. Jika terdapat indikator yang memiliki nilai korelasi dibawah 0,70, maka indikator tersebut harus dikeluarkan dari model. Karena indikator tersebut tidak valid berdasarkan kriteria penilaian PLS.

Berdasarkan Outer Loadings yang diperoleh, terdapat indikator yang dikeluarkan dari konstruk (model). Indikator tersebut, diantaranya adalah ICT infrastruktur yang diukur dengan menggunakan indikator $\mathrm{II}_{1}$ yang memiliki nilai 0,680 < 0,70 dan tidak signifikan, $\mathrm{II}_{4}$ yang memiliki nilai 0,691 < 0,70 dan tidak signifikan, serta $\mathrm{II}_{5}$ yang memiliki nilai 0,692 < 0,70 dan tidak signifikan; kinerja inovasi yang diukur dengan menggunakan indikator $\mathrm{IP}_{6}$ yang memiliki nilai $0,348<0,70$ dan tidak signifikan, $\mathrm{IP}_{7}$ yang memiliki nilai 0,684 dan tidak signifikan, $\mathrm{IP}_{10}$ yang memiliki nilai 0,699 dan tidak signifikan, serta $\mathrm{IP}_{11}$ yang memiliki nilai $0,670<0,70$ dan tidak signifikan.

Setelah dilakukan penghapusan konstruk dikarenakan indikator kurang dari 0,70, maka tidak ada indikator yang dikeluarkan dari konstruk (model). Karena nilai setiap indikator lebih dari 0,70. Berarti, indikator yang digunakan dalam penelitian ini adalah valid atau telah memenuhi convergent validity. Discriminant validity indikator reflektif dapat dilihat pada cross-loading antara indikator di tabel 1.

Tabel 1. Discriminant Validity Cross-Loading

\begin{tabular}{lccccc}
\hline & $\begin{array}{c}\text { ICT } \\
\text { Departemen }\end{array}$ & $\begin{array}{c}\text { ICT } \\
\text { Infrastruktur }\end{array}$ & $\begin{array}{c}\text { ICT } \\
\text { Personel }\end{array}$ & $\begin{array}{c}\text { ICT } \\
\text { Training }\end{array}$ & Kinerja Inovasi \\
\hline ICP1 & 0,708 & 0,754 & 0,908 & 0,706 & 0,515 \\
ICP2 & 0,751 & 0,762 & 0,948 & 0,726 & 0,570 \\
ICP3 & 0,711 & 0,756 & 0,953 & 0,710 & 0,594 \\
ID1 & 0,937 & 0,783 & 0,666 & 0,687 & 0,614 \\
ID2 & 0,903 & 0,743 & 0,768 & 0,664 & 0,500 \\
II2 & 0,777 & 0,843 & 0,596 & 0,649 & 0,666 \\
II3 & 0,738 & 0,802 & 0,699 & 0,596 & 0,478 \\
II6 & 0,592 & 0,816 & 0,542 & 0,685 & 0,599 \\
II7 & 0,606 & 0,814 & 0,555 & 0,701 & 0,588 \\
II8 & 0,658 & 0,811 & 0,746 & 0,712 & 0,600 \\
II9 & 0,632 & 0,725 & 0,817 & 0,594 & 0,474 \\
IP1 & 0,532 & 0,672 & 0,552 & 0,669 & 0,815 \\
IP12 & 0,501 & 0,582 & 0,498 & 0,529 & 0,783 \\
IP2 & 0,498 & 0,601 & 0,399 & 0,496 & 0,836 \\
IP3 & 0,491 & 0,582 & 0,451 & 0,595 & 0,840 \\
IP4 & 0,520 & 0,557 & 0,508 & 0,559 & 0,822 \\
IP5 & 0,474 & 0,565 & 0,466 & 0,566 & 0,771 \\
IP8 & 0,419 & 0,449 & 0,475 & 0,497 & 0,739 \\
IP9 & 0,440 & 0,509 & 0,458 & 0,527 & 0,756 \\
IT1 & 0,683 & 0,737 & 0,763 & 0,856 & 0,563 \\
IT2 & 0,630 & 0,771 & 0,626 & 0,927 & 0,645 \\
IT3 & 0,660 & 0,692 & 0,665 & 0,894 & 0,664 \\
\hline Iumber & & & & \\
\hline
\end{tabular}

Sumber: Data Penelitian, 2018 
Tabel 1 menjelaskan korelasi hubungan antara variabel dengan indikator. Nilai kontruk ICT infrastruktur $\left(\mathrm{X}_{1}\right)$ lebih tinggi dengan indikator $\mathrm{II}_{2}$ sebesar 0,843 . Nilai kontruk ICT personel $\left(\mathrm{X}_{2}\right)$ lebih tinggi dengan indikator $\mathrm{ICP}_{3}$ sebesar 0,953. Nilai kontruk ICT training $\left(X_{3}\right)$ lebih tinggi dengan indikator $\mathrm{IT}_{2}$ sebesar 0,927. Nilai konstruk ICT departemen $\left(X_{4}\right)$ lebih tinggi dengan indikator ID $_{1}$ sebesar 0,937 . Nilai kontruk kinerja inovasi $(\mathrm{Y})$ lebih tinggi dengan indikator $\mathrm{IP}_{3}$ sebesar 0,840. Dengan demikian, kontrak laten memprediksi indikator pada blok mereka lebih baik dibandingkan dengan indikator di blok yang lain.

Tabel 2. Discriminant Validity Fornell-Larcker Criterion

\begin{tabular}{lccccc}
\hline & $\begin{array}{c}\text { ICT } \\
\text { Departemen }\end{array}$ & $\begin{array}{c}\text { ICT } \\
\text { Infrastruktur }\end{array}$ & $\begin{array}{c}\text { ICT } \\
\text { Personel }\end{array}$ & $\begin{array}{c}\text { ICT } \\
\text { Training }\end{array}$ & $\begin{array}{c}\text { Kinerja } \\
\text { Inovasi }\end{array}$ \\
\hline ICT Departemen & 0,920 & & & & \\
ICT Infrastruktur & 0,830 & 0,803 & & & \\
ICT Personel & 0,772 & 0,808 & 0,936 & & \\
ICT Training & 0,734 & 0,820 & 0,762 & 0,893 & \\
Kinerja Inovasi & 0,611 & 0,715 & 0,599 & 0,701 & 0,796 \\
\hline
\end{tabular}

Sumber : Data Penelitian, 2018

Tabel 2 menjelaskan korelasi hubungan antara variabel dengan variabel lainnya, dimana konstruk ICT infrastruktur $\left(\mathrm{X}_{1}\right)$ lebih tinggi dengan konstruk ICT departemen sebesar 0,830. Sedangkan, ICT personel $\left(X_{2}\right)$ lebih tinggi dengan konstruk ICT personel sebesar 0,936. Sedangkan, nilai konstruk ICT training $\left(X_{3}\right)$ lebih tinggi dengan konstruk ICT training sebesar 0,893. Sedangkan, nilai konstruk ICT departemen $\left(\mathrm{X}_{4}\right)$ lebih tinggi dengan konstruk ICT departemen sebesar 0,920. Sedangkan, konstruk kinerja inovasi (Y) lebih tinggi dengan konstruk kinerja inovasi sebesar 0,796. Dengan demikian, kontrak laten memprediksi variabel pada blok mereka lebih baik dibandingkan dengan indikator di blok yang lain.

Metode lain untuk melihat discriminant validity adalah dengan melihat nilai square root of average variance extracted (AVE). Nilai yang disarankan adalah di atas 0,5 .

Tabel 3. Construct Reliability and Validity

\begin{tabular}{lccc}
\hline & $\begin{array}{c}\text { Cronbach's } \\
\text { Alpha }\end{array}$ & $\begin{array}{c}\text { Composite } \\
\text { Reliability }\end{array}$ & $\begin{array}{c}\text { Average Variance } \\
\text { Extracted (AVE) }\end{array}$ \\
\hline ICT Departemen & 0,820 & 0,917 & 0,846 \\
ICT Infrastruktur & 0,890 & 0,916 & 0,644 \\
ICT Personel & 0,929 & 0,955 & 0,876 \\
ICT Training & 0,872 & 0,922 & 0,797 \\
Kinerja Inovasi & 0,917 & 0,932 & 0,634 \\
\hline
\end{tabular}

Sumber : Data Penelitian, 2018

Tabel 3 memberikan nilai Average Variance Extracted (AVE) di atas 0,50 untuk semua konstruk yang terdapat pada model penelitian. Nilai Average Variance Extracted (AVE) pada konstruk ICT infrastruktur $\left(\mathrm{X}_{1}\right)$ sebesar 0,644, konstruk ICT personel $\left(\mathrm{X}_{2}\right)$ sebesar 0,876 , konstruk ICT training $\left(\mathrm{X}_{3}\right)$ sebesar 0,797, dan konstruk ICT departemen $\left(\mathrm{X}_{4}\right)$ sebesar 0,846. Sedangkan, nilai Average Variance Extracted (AVE) pada kinerja inovasi (Y) sebesar 0,634.

Inner model dapat dilihat dari nilai Composite Reliability dari blok indikator yang mengukur konstruk. Hasil Composite Reliability akan menunjukkan nilai yang memuaskan jika di atas 0,700. Tabel diatas menunjukkan bahwa nilai 
Composite Reliability untuk semua konstruk adalah di atas 0,700 yang menunjukkan bahwa semua konstruk pada model yang diestimasi memenuhi kriteria Discriminant Validity. Nilai Composite Reliability sebesar 0,916 pada konstruk ICT infrastruktur $\left(X_{1}\right), 0,955$ pada konstruk ICT personel $\left(X_{2}\right), 0,922$ pada konstruk ICT training $\left(X_{3}\right)$, dan 0,917 pada konstruk ICT departemen $\left(X_{4}\right)$. Sedangkan, nilai Composite Reliability pada kinerja inovasi (Y) sebesar 0,932.

Pengujian terhadap model struktural dilakukan dengan melihat $R$-Square yang merupakan uji goodness fit model. Setelah model yang diestimasi memenuhi kriteria Outer Model, berikutnya dilakukan pengujian model struktural (Inner model). Pengujian inner model dapat dilihat dari nilai $R$-Square dan $R$ Square Adjusted pada konstruk. Model pengaruh ICT infrastruktur $\left(\mathrm{X}_{1}\right)$, ICT personel $\left(\mathrm{X}_{2}\right)$, ICT training $\left(\mathrm{X}_{3}\right)$, dan ICT departemen $\left(\mathrm{X}_{4}\right)$ terhadap kinerja inovasi $(\mathrm{Y})$ memberikan nilai R-Square sebesar $55,2 \%$ yang dapat diinterpretasikan bahwa variabilitas ICT infrastruktur $\left(X_{1}\right)$, ICT personel $\left(X_{2}\right)$, ICT training $\left(X_{3}\right)$, dan ICT departemen $\left(\mathrm{X}_{4}\right)$ dapat dijelaskan oleh variabilitas kinerja inovasi (Y) sebesar 55,2 $\%$, sedangkan $44,8 \%$ dijelaskan oleh variabel lain diluar yang diteliti.

Ada empat hipotesis yang digunakan dalam penelitian ini. Hipotesishipotesis tersebut akan dilakukan pengujian dengan menggunakan metode persamaan struktural dengan pendekatan PLS (Partial Least Square), dengan menguji signifikansi koefisien jalur yang ada pada model. Jika $\mathrm{t}$-statistik pada jalur yang diuji $\geq 1,96$, maka hipotesis penelitian terbukti atau diterima. Hasil pengujian tersebut secara rinci dapat dilihat di tabel 4 .

Tabel 4. Path Coefficient

\begin{tabular}{llccccc}
\hline & $\begin{array}{c}\text { Original } \\
\text { Sample } \\
(\mathrm{O})\end{array}$ & $\begin{array}{c}\text { Sample } \\
\text { Mean }(\mathrm{M})\end{array}$ & $\begin{array}{c}\text { Standard } \\
\text { Deviation } \\
(\text { STDEV })\end{array}$ & $\begin{array}{c}\text { T-Statistics } \\
(\mid \mathrm{O} / \text { STDEV } \mid)\end{array}$ & $\begin{array}{c}\text { P- } \\
\text { Values }\end{array}$ \\
\hline $\begin{array}{l}\text { ICT departemen } \\
\text { kinerja inovasi }\end{array}$ & $->$ & 0,008 & 0,014 & 0,140 & 0,057 & 0,955 \\
$\begin{array}{l}\text { ICT infrastruktur } \\
\text { kinerja inovasi }\end{array}$ & 0,446 & 0,464 & 0,167 & 2,678 & 0,008 \\
$\begin{array}{l}\text { ICT personel } \\
\text { kinerja inovasi } \\
\text { ICT training } \\
\text { kinerja inovasi }\end{array}$ & $-0,044$ & $-0,009$ & 0,238 & 0,187 & 0,852 \\
\hline
\end{tabular}

Sumber : Data Penelitian, 2018

Tabel 4 menunjukkan bahwa hubungan antara ICT infrastruktur $\left(\mathrm{X}_{1}\right)$ terhadap kinerja inovasi $(\mathrm{Y})$ adalah signifikan dengan T-statistik sebesar 2,678 $(>1,96)$. Nilai original sample estimate adalah positif yaitu sebesar 0,446 yang menunjukkan bahwa arah hubungan antara ICT infrastruktur $\left(\mathrm{X}_{1}\right)$ terhadap kinerja inovasi (Y) adalah positif. Dapat diartikan bahwa semakin canggih ICT infrastruktur, maka kinerja inovasi akan semakin meningkat. ICT infrastruktur menjadi pondasi dasar dibagian IT perusahaan (Armstrong \& Sambamurthy, 1999). Dengan demikian, hipotesis dalam penelitian ini yang menyatakan bahwa ICT infrastruktur berpengaruh terhadap kinerja inovasi, diterima $\left(\mathrm{H}_{1}\right.$ diterima).

ICT infrastruktur membantu karyawan dalam melaksanakan kegiatan operasional perusahaan. Semakin canggih ICT infrastruktur membuat karyawan lebih mudah mengakses pengetahuan terkait dengan inovasi sehingga muncul inovasi baru terkait dengan proses, produk, dan layanan. Sejalan dengan theory 
acceptance model (TAM), karena karyawan menyakini bahwa ICT berguna bagi peningkatan kinerja inovasi, maka ICT infrastruktur berpengaruh secara maksimal dalam meningkatan kinerja inovasi.

Hubungan antara ICT personel $\left(\mathrm{X}_{2}\right)$ terhadap kinerja inovasi $(\mathrm{Y})$ adalah tidak signifikan dengan T-statistik sebesar 0,187 $(<1,96)$. Nilai original sample estimate adalah negatif yaitu sebesar 0,044 yang menunjukkan bahwa arah hubungan antara ICT personel $\left(\mathrm{X}_{2}\right)$ terhadap kienrja inovasi $(\mathrm{Y})$ adalah negatif. Dapat diartikan bahwa semakin banyak jumlah ICT personel, maka kinerja inovasi akan meningkat. Namun, berdasarkan hasil statistik, ICT personel tidak berpangaruh secara signifikan terhadap kinerja inovasi. Hal itu disebabkan karena ICT personel harus memenuhi kualifikasi sebagai dalam melaksanakan pekerjaannya, baik karyawan tersebut mempunyai pengalaman atau tidak dalam pekerjaannya. Dengan demikian, hipotesis dalam penelitian ini yang menyatakan bahwa ICT personel berpengaruh terhadap kinerja inovasi, ditolak $\left(\mathrm{H}_{2}\right.$ ditolak).

ICT personel mempunyai pengetahuan mengenai hard ICT capital. Kombinasi pengetahuan antara pengetahuan ICT dan personil operasi (seperti tenaga penjualan) dapat mengarah pada gagasan untuk inovasi produk dan layanan baru berbasis ICT. Berdasarkan theory acceptance model, karyawan meyakini bahwa pengetahuan terkait teknologi dapat menciptakan inovasi baru. Selain itu, karyawan harus memiliki pengetahuan teknologi untuk meningkatkan pemahaman teknologi mengenai teknologi di aktivitas bisnis mereka (Armstrong \& Sambamurthy, 1999). Namun, hasil statistik menunjukkan bahwa karyawan kurang yakin atas pengetahuan yang dimiliki sehingga inovasi yang diciptakan tidak maksimal (Folkinshteyn \& Lennon, 2016; McFarland \& Hamilton, 2006; Pituch \& Lee, 2006). Oleh karena itu, ICT personel tidak dapat mempengaruhi kinerja inovasi.

Hubungan antara ICT training $\left(\mathrm{X}_{3}\right)$ terhadap kinerja inovasi $(\mathrm{Y})$ adalah signifikan dengan T-statistik sebesar 2,507 $(>1,96)$. Nilai original sample estimate adalah positif yaitu sebesar 0,364 yang menunjukkan bahwa arah hubungan antara ICT training $\left(\mathrm{X}_{3}\right)$ terhadap kinerja inovasi $(\mathrm{Y})$ adalah positif. Dapat diartikan bahwa semakin sering karyawan mengikuti pelatihan, maka kinerja inovasi akan semakin meningkat. Hal itu disebabkan karena karyawan mendapat banyak pengetahuan, baik pengetahuan lama maupun pengetahuan baru mengenai ICT yang mendukung kinerja inovasi perusahaan. Sejalan dengan (Chang \& Tung, 2008; J. Wu et al., 2006) bahwa karyawan yang lebih berpengetahuan, maka sistem yang berbasis ICT dapat berjalan dengan lebih efektif. Dengan demikian, hipotesis dalam penelitian ini yang menyatakan bahwa ICT training berpengaruh terhadap kinerja inovasi, diterima $\left(\mathrm{H}_{3}\right.$ diterima).

Evolusi ICT yang cepat dapat menghasilkan teknologi baru yang meningkatkan kemampuan dan fleksibilitas dari teknologi yang sudah ada, sehingga menciptakan peluang besar dalam menghasilkan inovasi-inovasi baru (Pawlowski \& Robey, 2004; Shih et al., 2011). Evolusi ICT yang cepat menuntut karyawan untuk terus memperkaya keterampilan dan pengetahuan ICT dengan cara mengikuti pelatihan. Hal tersebut dapat membuat karyawan untuk menghasilkan inovasi-inovasi baru. Berdasarkan theory acceptance model, 
karyawan meyakini bahwa mengikuti pelatihan terkait dengan ICT dapat meningkatkan keahlian dan pengetahuan mereka (Vilaseca-Requena et al., 2007), sehingga kinerja mereka akan lebih efektif dan efisien. Hal itu akan berdampak pada peningkatan kinerja inovasi (Wang \& Cheung, 2018). Oleh karena itu, ICT training dapat meningkatkan kinerja inovasi.

Hubungan antara ICT departemen $\left(\mathrm{X}_{4}\right)$ terhadap kinerja inovasi $(\mathrm{Y})$ adalah tidak signifikan dengan T-statistik sebesar $0,057(<1,96)$. Nilai original sample estimate adalah positif yaitu sebesar 0,008 yang menunjukkan bahwa arah hubungan antara ICT departemen $\left(\mathrm{X}_{4}\right)$ terhadap kinerja inovasi $(\mathrm{Y})$ adalah positif. Dapat diartikan bahwa semakin sering ICT departemen berbagi informasi kepada CEO dan divisi lainnya mengenai ICT, maka kinerja inovasi perusahaan akan semakin meningkat. Namun, berdasarkan hasil statistik, ICT departemen tidak signifikan berpengaruh terhadap kinerja inovasi. Hal itu disebabkan karena ICT departemen belum ada kemudahan akses informasi dan pemindahan data dengan baik oleh ICT departemen, atau terjadinya human error dalam proses pemindahan data (Gray et al., 2013; Stoner \& Sangster, 2013). Dengan demikian, hipotesis dalam penelitian ini yang menyatakan bahwa ICT departemen berpengaruh terhadap kinerja inovasi, ditolak $\left(\mathrm{H}_{4}\right.$ ditolak).

ICT departemen melaporkan kinerjanya kepada CEO perusahaan. Adanya transfer pengetahuan pada saat pelaporan kinerja menciptakan peluang bagi perusahaan untuk lebih berinovasi terhadap produk dan layanan. Berdasarkan theory acceptance model, karyawan meyakini bahwa pelaporan kinerja dapat memberikan informasi terkait inovasi kepada CEO perusahaan. Namun, hasil statistik menunjukkan bahwa karyawan tidak percaya atas hasil dari kinerja dan informasi yang mereka berikan kepada CEO perusahaan. Hasil tersebut sejalan dengan Nunnally (1978) bahwa ada kemungkinan hasil dari kinerja dimanipulasi sebelumnya oleh karyawan lain, sehingga tidak ada peningkatan terkait dengan kinerja inovasi. Oleh karena itu, ICT departemen tidak mempengaruhi kinerja inovasi.

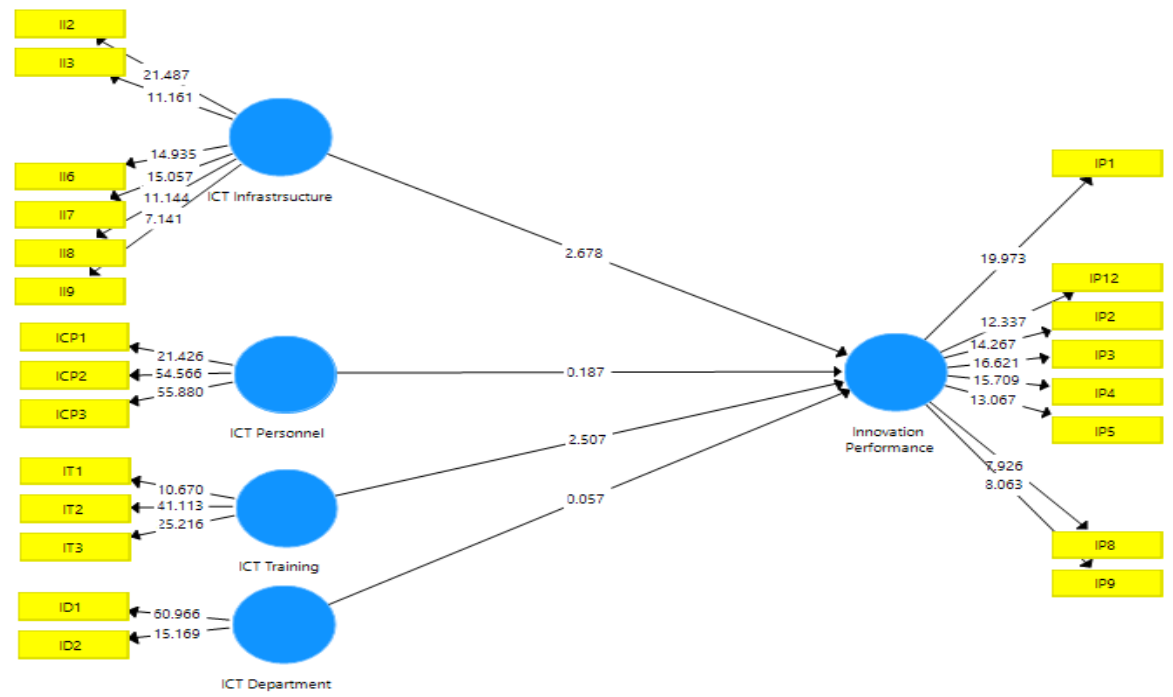

Gambar 2. Output Bootstrapping

Sumber: Data Penelitian, 2018 


\section{SIMPULAN}

Penelitian ini bermaksud untuk mengetahui bagaimana pengaruh ICT infrastruktur, ICT personel, ICT training, dan ICT departemen terhadap kinerja inovasi. Penelitian ini menggunakan perusahaan menufaktur sebagai subjek penelitian karena perusahaan manufaktur lebih relevan dengan topik inovasi. Perusahaan manufaktur lebih banyak berinovasi dalam mengembangkan produk dan layanan mereka untuk memenuhi keinginan konsumen. Hasil penelitian menunjukkan bahwa ICT infrastruktur dan ICT training berpengaruh signifikan terhadap kinerja inovasi. Sedangkan, ICT personel dan ICT departemen tidak berpengaruh terhadap kinerja inovasi. Hal itu disebabkan karena ICT personel harus mengikuti alur kerja perusahaan dan harus memenuhi kualifikasi yang diminta oleh perusahaan, sementara dalam ICT departemen belum ada kemudahan akses informasi dan pemindahan data secara baik. ICT infrastruktur dan ICT training berperan penting dalam kinerja inovasi perusahaan. ICT infrastruktur menjadi pondasi dasar perusahaan untuk melaksanakan kegiatan operasional perusahaan. ICT training memberikan pengetahuan baru bagi karyawan perusahaan mengenai ICT yang dapat membuat inovasi-inovasi baru, baik dalam proses, produk maupun layanan. Penelitian selanjutnya diharapkan dapat menambah variabel lain yang dapat mempengaruhi kinerja inovasi dan jumlah data penelitian, sehingga penelitian dapat mencerminkan kondisi yang sesungguhnya. Penelitian selanjutnya juga diharapkan menguji dampak ICT terhadap kinerja inovasi yang lebih kompleks.

\section{REFERENSI}

Ardhiani, L. N. (2015). Analisis Faktor-Faktor Penerimaan Penggunaan Quiooerschool.com dengan Menggunakan Pendekatan Technology Acceptance Model (TAM) dan Theory of Planned Behavior (TPB) di SMA Negeri 7 Yogyakarta. https://doi.org/10.1017/CBO9781107415324.004

Armstrong, C. P., \& Sambamurthy, V. (1999). Information Technology Assimilation in Firms : The Influence of Senior Leadership and IT Infrastructures. Information Systems Research, 10(4), 304-327.

Arvanitis, S., Loukis, E., \& Diamantopoulou, V. (2013). The Effect of Soft ICT Capital on Innovation Performance of Greek Firms. Journal of Enterprise Information Management, 26(6), 679-701. https://doi.org/10.1108/JEIM-072013-0048

Banker, R., Hu, N., Pavlou, P., \& Luftman, J. (2011). CIO Reporting Structure, Strategic Positioning and Firm Performance. MIS Quarterly, 35(2), 487-504.

Barney, J. (1991). Firm Resources and Sustained Competitives Advantage. Journal of Management, 17(1), 99-120.

Bharadwaj, A. S. (2000). A Resource-Based Perspective on Information Technology Capability and Firm Performance: An Empirical Investigation. MIS Quarterly, 24(1), 169-196.

Bresnahan, T. F., Brynjolfsson, E., \& Hitt, L. M. (2002). Information Technology, Workplace Organization, and The Demand for Skilled Labor: Firm-Level Evidence. Quarterly Journal of Economics, (February).

Bresnahan, T. F., \& Trajtenberg, M. (1995). General Purpose Technologies: 
Engines of Growth. Journal of Econometric, 65(1), 83-108.

Brynjolfsson, E., \& Hitt, L. (1996). Paradox lost? Firm-level evidence on the returns to information systems. Management Science, 42(4), 541-558. https://doi.org/10.1287/mnsc.42.4.541

Cassiman, B., \& Veugelers, R. (2006). In Search of Complementarity in Innovation Strategy : Internal R \& D and External Knowledge Acquisition. Management Science, 52(1), 68-82. https:/ / doi.org/10.1287/mnsc.1050.0470

Chang, S. C., \& Tung, F. C. (2008). An empirical investigation of students' behavioural intentions to use the online learning course websites. British Journal of Educational Technology, 39(1), 71-83. https://doi.org/10.1111/j.1467-8535.2007.00742.x

Chen, D. Q., Preston, D. S., \& Xia, W. (2010). Antecedents and Effects of CIO Supply-Side and Demand-Side Leadership : A Staged Maturity Model. Journal of Management Information Systems, 27(1), 231-271. https://doi.org/10.2753/MIS0742-1222270110

Chesbrough, H., \& Crowther, A. K. (2006). Beyond High Tech : Early Adopters of Open Innovation in Other Industries. RED Management, 36(3), 229-236.

Chesbrough, H. W. (2003). Open Innovation: The New Imperative for Creating and Profiting from Technology. Boston: Harvard Business School Press.

Davenport, T. H. (1993). Reengineering Work through Information Technology. Harvard Business School Press. https://doi.org/10.1177/1354066102008003004

Davis, F. D. (1986). A Technology Acceptance Model for Empirically Testing New EndUser Information Systems: Theory and Results. Sloan School of Management. Retrieved from http://www.ncbi.nlm.nih.gov/pubmed/14224511

Davis, F. D. (1989). Perceived Usefulness, Perceived Ease of Use, and User Acceptance of Information Technology. MIS Quarterly, 13(September), 319340. https://doi.org/10.2307/249008

Davis, F. D., Bagozzi, R. P., \& Warshaw, P. R. (1989). User Acceptance of Computer Technology: A Comparison of Two Theoretical Models. Management Science, 35(8), 982-1003. https:// doi.org/10.1287/mnsc.35.8.982

Folkinshteyn, D., \& Lennon, M. (2016). Braving Bitcoin: A technology acceptance model (TAM) analysis. Journal of Information Technology Case and Application Research, 18(4), 220-249. https:/ / doi.org/10.1080/15228053.2016.1275242

Gordon, S., Tarafdar, M., Cook, R., Maksimoski, R., \& Rogowitz, B. (2008). Improving the Front End of Innovationwith Information Technology. Research Technology Management, 51(3), 50-58.

Gray, W. D., Sabnani, H., \& Kirschenbaum, S. S. (2013). Review of Human error. In Human Factors on the Flight Deck: Safe Piloting Behaviour in Practice (Vol. 9783642317, pp. 59-86). https:// doi.org/10.1007/978-3-642-31733-0_3

Kleis, L., Chwelos, P., Ramirez, R., \& Cockburn, I. (2012). Information Technology and Intagible Output: The Impact of IT Investment on Innovation Productivity. Information Systems Research, 23(1), 42-59.

Mafabi, S., Munene, J. C., \& Ahiauzu, A. (2015). Creative Climate and Organizational Resilience: The Mediating Role of Innovation. International Journal of Organizational Analysis, 23(4), 564-587.

Mata, F. J., Fuerst, W. L., \& Barney, J. B. (1995). InformationTechnology and 
Sustained Competitive Advantage: A Resource-Based Analysis. MIS Quarterly, 19(4), 487-505.

McFarland, D. J., \& Hamilton, D. (2006). Adding contextual specificity to the technology acceptance model. Computers in Human Behavior, 22(3), 427-447. https://doi.org/10.1016/j.chb.2004.09.009

Nunnally, J. C. (1978). Psychometric theory. McGraw-Hill Series in Psychology, 4(10), xiii, 640 p. https://doi.org/10.1109/PROC.1975.9792

Pawlowski, S. D., \& Robey, D. (2004). Bridging User Organizations: Knowledge Brokering and the Work of Information Technology Professionals. MIS Quarterly, 28(4), 645-672.

Pituch, K. A., \& Lee, Y. kuei. (2006). The influence of system characteristics on elearning use. Computers and Education, 47(2), 222-244. https://doi.org/10.1016/j.compedu.2004.10.007

Ravichandran, T., \& Lertwongsatien, C. (2005). Effect of Information Systems Resources and Capabilities on Firm Performance: A Resource-based Perspective. Journal of Management Information Systems, 21(4), 237-276.

Shih, S., Jiang, J. J., Klein, G., \& Wang, E. (2011). Learning Demand and Job Autonomy of IT Personnel: Impact on Turnover Intention. Computers in Human Behavior, 27(6), 2301-2307. https:// doi.org/10.1016/j.chb.2011.07.009

Stoner, G. N., \& Sangster, A. (2013). Teaching IFRS in the U.K.: Contrasting experiences from both sides of the university divide. Issues in Accounting Education, 28(2), 291-307. https://doi.org/10.2308/iace-50357

Syed-Ikhsan, S. O. S., \& Rowland, F. (2011). Benchmarking Knowledge Management in A Public Organization in Malaysia. Computers in Human Behavior, 27(27), 2301-2307.

Thomke, S. H. (2006). Capturing the Real Value of Innovation Tools. MIT Sloan Management Review, 47(2), 24-32.

Vilaseca-Requena, J., Torrent-Sellens, J., Meseguer-Artola, A., \& RodríguezArdura, I. (2007). An integrated model of the adoption and extent of ecommerce in firms. International Advances in Economic Research, 13(2), 222241. https://doi.org/10.1007/s11294-006-9061-z

Wade, M., \& Hulland, J. (2004). Review: The Resource-based view and Information Systems Research: Review, Extension, and Suggestions for Future Research. MIS Quarterly, 28(1), 107-142.

Wang, S., \& Cheung, W. (2018). E-Business Adoption by Travel Agencies : Prime Candidates for Mobile e-Business Linked references are available on JSTOR for this article: E-Business Adoption by Travel Agencies : Prime Candidates for Mobile e-Business. International Journal of Electronic Commerce, 8(3), 43-63.

Wu, J. H., \& Hisa, T. L. (2008). Developing E-business Dynamic Capabilities: An Analysis of E-Commerce Innovation from I-, M-, to U-Commerce. Journal of Organizational Computing and Electronic Commerce, 18(2), 95-111. https://doi.org/10.1080/10919390701807525

Wu, J., Tsai, R. a Y. J., Chen, C. C., \& Wu, Y. (2006). An Integrative Model to Predict the Continuance Use of Electronic Learning Systems: Hints for Teaching. International Journal on E-Learning, 5(2), 287-302. 